\title{
Public libraries embrace citizen science: Strengths and challenges
}

\author{
Anna Cigarini ${ }^{\mathrm{a}, \mathrm{b}, \mathrm{c}}$, Isabelle Bonhoure ${ }^{\mathrm{a}, \mathrm{b}}$, Julián Vicens ${ }^{\mathrm{a}, \mathrm{b}}$, Josep Perelló ${ }^{\mathrm{a}, \mathrm{b}, *}$ \\ ${ }^{a}$ OpenSystems Research Group, Departament de Física de la Matèria Condensada, Universitat de Barcelona, Martí i Franquès, 1, Barcelona 08028, Spain \\ ${ }^{\mathrm{b}}$ Universitat de Barcelona Institute of Complex Systems UBICS, Martí i Franquès, 1, 08028 Barcelona, Spain \\ ${ }^{\mathrm{c}}$ Dimmons Research Group, Internet Interdisciplinary Institute (IN3), Universitat Oberta de Catalunya, Avinguda Carl Friedrich Gauss, 5, 08860 Castelldefels, Barcelona, \\ Spain
}

\section{A R T I C L E I N F O}

\section{Keywords:}

Engagement

Citizen social science

Co-creation

Public library

Learning

Self-efficacy

Scientific citizenship

Science education

Public participation

Scientific literacy

\begin{abstract}
A B S T R A C T
Can public libraries become hubs for citizen science? In line with the principles of citizen science, this question was answered collaboratively with librarians from the Barcelona Network of Public Libraries who performed two hands-on activities. One activity was a training course taken by 30 librarians from 24 different libraries which enabled them to envisage citizen science implementation at each library. The other activity consisted of cocreating a citizen social science project and involved 40 library users, seven librarians from three different cities, and professional scientists. The analysis considers the perspectives of both librarians and users, through participant observation, surveys, and a focus group to identify strengths and challenges. The overall results suggest that public libraries can offer leadership in the promotion of citizen science and contribute to the mission of public libraries to act as local community hubs. The main challenges identified were related to the complexity of collaboration, uncertainty regarding research co-creation, and participant retention strategies.
\end{abstract}

\section{Introduction}

The societal context in which libraries operate is changing rapidly. Libraries face various challenges related to changing practices, services, and users' expectations and behavior. The digital revolution, in particular, has dramatically tested the role and social value of the public library as an institution within society (Greenhalgh \& Worpole, 2013; Leckie \& Hopkins, 2002). It has emphasized the need for meeting places with the capacity to promote social inclusion, and a minimal degree of communality in terms of values, norms, and bridging social capital (Aabø, Audunson, \& Vårheim, 2010). As libraries struggle to keep pace with the changing societal landscape, they are incorporating emerging practices such as citizen science (CS) into the services they offer in order to reinforce the idea of public libraries as spaces for gathering, meeting, and collaboration, within the context of shared community and shared learning resources.

CS has gained considerable momentum in recent years (Sauermann et al., 2020). It plays an important role in implementing the broader idea of Open Science (Ayris \& Ignat, 2018; League of European Research Universities, 2018), which in turn marks a necessary cultural change in the way research, education and innovation are undertaken. Beyond open access to data, publications, and other research outputs, CS facilitates the active participation of citizens in the scientific research process (Wehn, Gobel, Bowser, Hepburn, \& Haklay, 2020). CS is thus both an aim and an enabler of Open Science. On the one hand, it presents the means for open, holistic and participatory processes of knowledge generation; on the other, it favors openness that, as opposed to secrecy or exclusion, is key for the sustainability, accessibility and quality of scientific knowledge produced through citizen participation. Since libraries constitute infrastructure that is central for Open Science, their embracing of CS might contribute to facilitating the transition to more open knowledge.

\section{Problem statement}

Although there have been a few, albeit limited, discussions in the context of European and American research libraries (Ayris \& Ignat, 2018; Ignat et al., 2018, Ignat, Cavalier, \& Nickerson, 2019; Wiederkehr, 2019;), there is no empirical evidence concerning whether the most open and participatory practices adopted in CS can converge with and be nurtured by the essence of public libraries. Moreover, the roles of both librarians and users in the 'next generation public library' remain

\footnotetext{
* Corresponding author at: OpenSystems Research Group, Departament de Física de la Matèria Condensada, Universitat de Barcelona, Martí i Franquès, 1, Barcelona 08028, Spain.

E-mail address: josep.perello@ub.edu (J. Perelló).
} 
underdeveloped. As the number of CS initiatives at public libraries grows, so does the need for evidence of the impact of those CS practices and the capacity of libraries to assimilate them. Accordingly, this study addresses the following questions:

- Can public libraries embrace CS practices?

- What are the main strengths of public libraries when it comes to assimilating CS practices?

- What are the main challenges public libraries face when assimilating CS practices?

\section{Literature review}

CS broadly refers to the active engagement of the general public in scientific research tasks that have traditionally been undertaken by scientists. The literature reports the contributions of CS to research (Dickinson et al., 2012; McKinley et al., 2017), science education (Bonney, Phillips, Ballard, \& Enck, 2016) and environmental advocacy (Haywood, Parrish, \& Dolliver, 2016; Johnson et al., 2014). CS has also generated high expectations concerning its current and potential capacity as a means of addressing some major and highly complex socioenvironmental challenges (Fraisl et al., 2020; Sauermann et al., 2020).

Many CS projects are intentionally designed to answer important scientific questions or to meet specific educational objectives, and thus are not intended to democratize science or to lead to outcomes that promote social justice (Bonney et al., 2016). In contrast, co-created CS projects may entail the greatest transformative potential and have the widest range of impacts on public understanding (Irwin, 1995; Shirk et al., 2012). Participation in such projects moves beyond the collection of data and builds collective development of research questions, the design of research protocols, data interpretation and the dissemination of results. A co-created project combines science engagement with the goals of public engagement in governance and science-based decisionmaking, as Irwin (1995) proposed two decades ago, and it can eventually be framed as 'citizen social science', understood as research codesigned and driven by groups sharing social concerns (Bonhoure, Cigarini, Vicens, \& Perelló, 2019).

\subsection{Citizen science at public libraries}

The digital age has caused public libraries to undergo major transformations (Greenhalgh \& Worpole, 2013; Leckie \& Hopkins, 2002). A recent large-scale survey of citizen perceptions and support for public libraries suggests that public libraries and their uses need to be redesigned so that, as well as being quiet places with books and a fast Internet connection, they can become community hubs in which library professionals take on active roles (OCLC \& American Library Association, 2018).

Within this context, makerspaces are being incorporated into public libraries, providing users with an informal learning environment where they can practice hands-on exploration, ranging from 3D printing and multimedia, to art carts and building stations (Moorefield-Lang, 2015; Willett, 2018). These emerging practices nurture curiosity and motivation to learn through making, while serving the goals of a public library. Beyond their infrastructure and contents, public libraries are indeed public sphere institutions with a higher role and calling (Ingraham, 2015). As reported in Aabø et al. (2010), public libraries are used as meeting places for activities related to different aspects of the public sphere, such as authors' nights or opportunities to learn about social issues at the library. Public libraries may function as instruments of social networking, integration, and dialogue, thus building social capital and playing a potentially important role in the integration of heterogeneous and diversified communities (Wojciechowska, 2020).

Different policies, recommendations, and practices in the United States and Europe are currently seeking to engage libraries with CS. The goal is to encourage librarians to leverage existing CS resources and take inspiration from successful international examples in order to allow their libraries to become hubs for CS, in line with global Open Science (Ayris \& Ignat, 2018; Ignat et al., 2019). The Open Science Roadmap of the European Association of Research Libraries (LIBER) emphasizes the importance of CS as part of cultural change and broadly endorses libraries as partners in CS. The League of European Research Universities (LERU), which comprises over 23 research-intensive European universities, analyzed CS trends and provides guidelines that range from raising awareness to developing assistance for CS in research funding and evaluation processes, thereby demonstrating institutional support for CS at the university level (League of European Research Universities, 2018).

In Europe and the Middle East, adopting CS at public libraries has taken a number of forms, from skills development, to building and maintaining collections of protocols, or developing and implementing a toolkit for CS projects (Ignat et al., 2018). In Switzerland, the ETH Library implemented an open data policy and used a crowdsourced CS model to improve its metadata. The citizen scientists contributed to improving the metadata, georeferenced maps and other materials, as well as identifying the themes of photographs, eventually enhancing the search tools of the ETH Library (Wiederkehr, 2019). In the United States, as part of an ongoing project called "Libraries as Community Hubs for Citizen Science", CS toolkits are being developed, evaluated, and made available for and through public library partners, while associated resources are created to train, support, and communicate with librarians and citizen scientists (SciStarter, 2019).

Overall, recent initiatives suggest that libraries in the United States and Europe are building on their existing activities and programs, capacity, and infrastructure in order to offer their communities opportunities to participate in scientific research through CS (Ignat et al., 2018). However, there remains work to be done to embed CS within the existing practices and functions of public libraries (League of European Research Universities, 2016).

\subsection{Theoretical framework}

Engagement in CS has typically been defined through behavioral patterns of quantity and quality of data contributions (Nov, Arazy, \& Anderson, 2014) such as participant numbers, or data collection and submission rates. Research has also indicated the value of engagement in terms of improvements in knowledge or scientific competences, greater interest in science, or confidence in one's ability to participate in scientific research (Bela et al., 2016; Bonney et al., 2016). However, engagement is a complex and multifaceted concept. It entails cognitive, affective, social, behavioral, and motivational dimensions that create opportunities for volunteers to find personal relevance in their work with scientists (Phillips, Ballard, Lewenstein, \& Bonney, 2019). Measuring engagement by quantifying contributions to data outputs alone leaves critical gaps in the full range of what engagement means and entails (Phillips et al., 2019).

Socio-psychological approaches center on the assumption that individuals live in a perceived world and thus respond to the world as they perceive and interpret it. The socio-psychological models on which research into engagement in CS is grounded range from experiential (Brossard, Lewenstein, \& Bonney, 2005), transformative (Bela et al., 2016) and situated-learning theories (Phillips et al., 2019), to selfdetermination and social movement theory (Nov et al., 2014). The analysis presented here extends such social-psychological models and draws on the Theory of Planned Behavior (TPB) (Ajzen, 1991), one of the most influential theories of human behavior, to explore the dynamics of the participation of librarians and users in a local CS project. According to TPB, the intention to remain engaged in CS activities is best predicted by positive views of CS (attitudes), favorable opinions of CS held by influential others (subjective norms), and by individual perceived ability to engage in CS (perceived behavioral control) (Ajzen, 1991). Therefore, in the current study the relationship between the 
attitudes that librarians and users have towards CS, their motivation to participate, their perceived ability to implement a CS project (for librarians) or to contribute to science (for library users), and the intention of participants to remain engaged with CS is examined.

\section{Methodology}

The one-year project (2018-2019) Citizen Science in Action promoted by the Barcelona Network of Public Libraries (Spain), which coordinates 225 libraries and $2.7 \mathrm{M}$ users is analyzed. The project was part of the Bibliolab program, whose broad aim is to promote new forms of open and creative collaboration between public libraries and the citizenry. The project was structured around two interdependent and hands-on activities offered to librarians as part of their lifelong training. The activities were: the Citizen Science Lab; and Science and Citizen Action.

The Citizen Science Lab consisted of an introductory course of 5 twohour CS capacitation sessions addressed at 30 librarians from 24 different libraries (see Fig. 1). As shown in Fig. 2 (top), the librarians were first presented with a general overview of CS (session I), next they were asked to test CS projects at their library (session II), and then they were asked to discuss the opportunities and challenges that CS could offer to library users, together with the aspects to be addressed when implementing a CS project at their library (session III). Based on both theoretical and practical activities, the librarians learned about CS practices, and they tested and eventually implemented existing CS projects at their library. As a result, the librarians' recommendations took the form of a collective toolkit for library users and other librarians that would empower them to implement and participate fully in CS projects at libraries (Perelló, Bonhoure, Cigarini, \& Vicens, 2019). The participants drafted the toolkit in the final two sessions.

At a higher level of engagement, the activity Science and Citizen Action involved 7 library professionals, who also participated in the Citizen Science Lab, from three municipalities within the Barcelona Metropolitan Area (Fort Pienc, Barcelona; Granollers; and Olesa de Montserrat), ranging from 24,000 to $1.5 \mathrm{M}$ inhabitants. The librarians

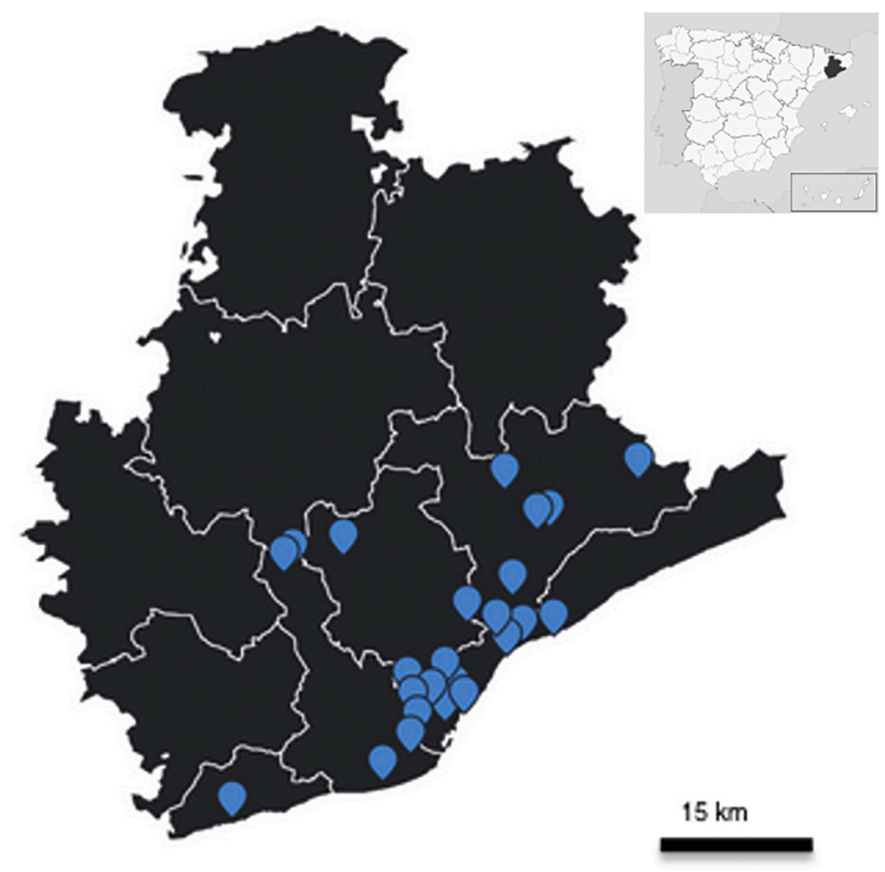

Fig. 1. Map of the Barcelona metropolitan area: In blue, the 24 public libraries that participate in the Citizen Science Lab, as reported in Data in Brief. (For interpretation of the references to colour in this figure legend, the reader is referred to the web version of this article.) were trained in co-creation and dynamic learning (Sanders \& Stappers, 2008) following the methodology developed in Senabre, Ferran-Ferrer, and Perelló (2018). Fig. 2 (bottom) represents the objectives and content of the 4 two-hour sessions: how to agree on the focus of the research, how to formulate the research question, how to plan the experimentation, and how to interpret the results. As shown in Fig. 2 (bottom), after each session, the librarians were asked to put the knowledge they had gained into practice by replicating the session within their community. In these sessions, they took on the role of facilitators, with the support of researchers. At each of the 3 subsequent sessions, the librarians then discussed the output of the work they had facilitated in their community. By the end of the third session, together they came up with a single design for research they agreed on for all three municipalities that addressed a common social concern: access to housing. A related behavioral experiment was carried out in a public space to bring libraries and librarians onto the streets and involved 358 participants. Framed as 'citizen social science' (Bonhoure et al., 2019), this activity thus placed the emphasis on the societal facet of CS practices. Behavioral data were collected by means of simulations of the housing market implemented on the Citizen Social Lab platform and following a game theoretical paradigm of strategic decision-making (Vicens, Perelló, \& Duch, 2018).

\subsection{Data collection}

For the Citizen Science Lab, data were collected via printed questionnaires, at the beginning and at the end of the activity. As shown in Fig. 2 (top), the questionnaires were handed out at the beginning of session I (which covered a general overview of CS), and at the end of session $\mathrm{V}$ (after finalizing the toolkit). Twenty-five responses to the first questionnaire, and 22 at the end of the course were collected. The majority of the librarians $(60 \%, n=15)$ had been working at their library for 11 to 20 years and only $4 \%(n=1)$ had a scientific background. Further details are provided in the Supplementary Information.

As shown in Fig. 2 (bottom), for the activity Science and Citizen Action, data on the engagement of the librarians with CS was collected via a focus group at the end of the project. The focus group addressed each element of the TPB model. Overall, seven librarians participated in the focus group, all but one were women and one was a library director.

To complement the perspectives expressed by the librarians, data on the perceptions of library users was also collected. Specifically, as Fig. 2 (bottom) shows, a printed questionnaire was handed to library users after the first session ("Definition of a social concern"), after the third session ("Design and planning of the experiment"), and after the fourth session ("Discussion of the results"). Responses to the first questionnaire were collected from 54 users and 23 valid responses to the last one were collected. On average, 40 library users, across the different libraries, participated in each of the four sessions. The majority of participants were women, in the age range $36-55$, and were representatives or members of local community associations. Further details are provided in the Data in Brief article.

\subsection{Data analysis}

Responses to closed survey questions were analyzed at a descriptive level because the reduced sample size did not allow for statistically significant testing. Thematic analysis on the qualitative feedback from the focus group and the open-ended survey question on motivation was conducted (Braun \& Clarke, 2006). This is a widely used method for identifying, analyzing, and reporting patterns within data inductively.

\section{Findings}

\subsection{Surveys}

The responses to the questionnaire administered at the end of the 

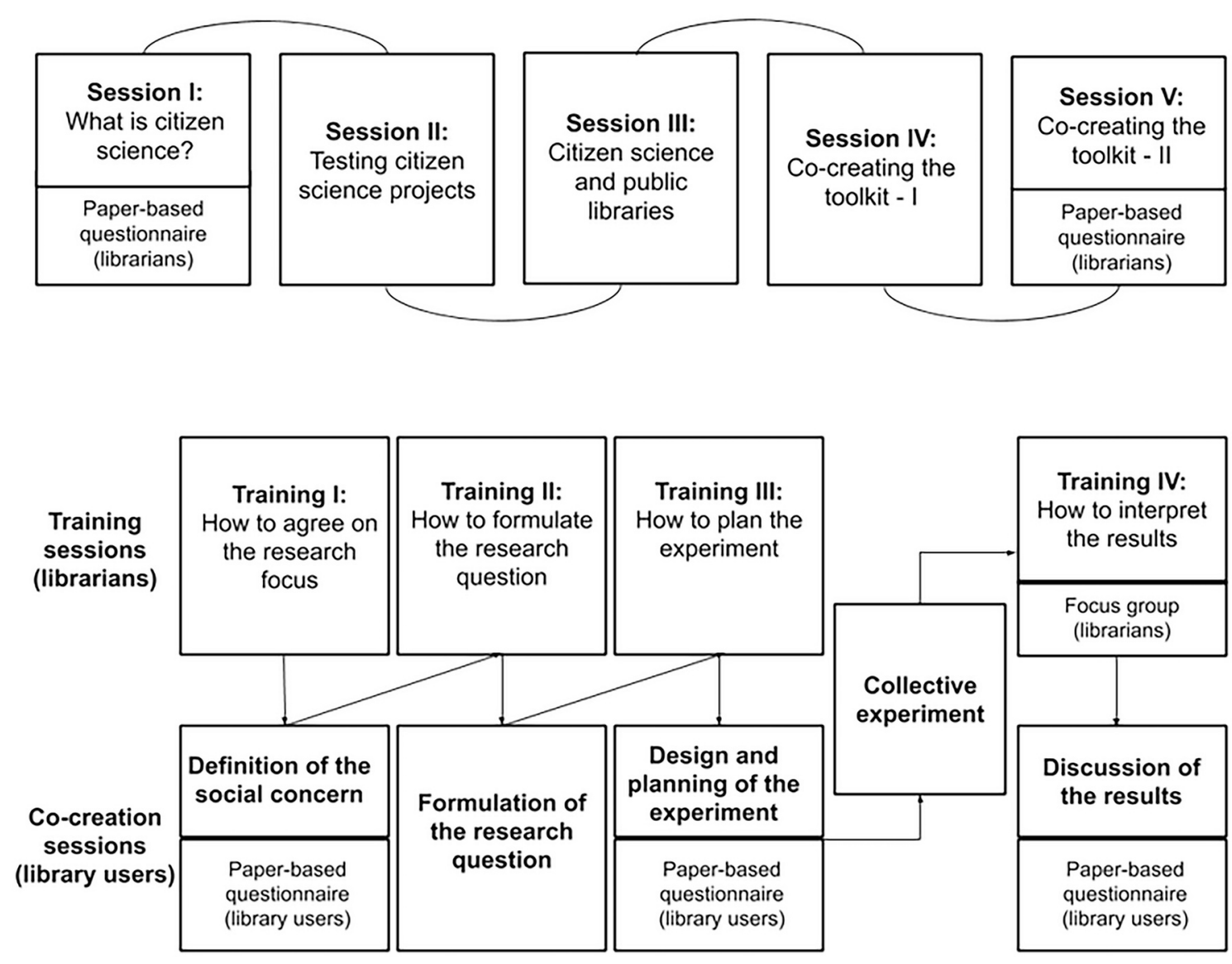

Fig. 2. The Citizen Science Lab (top) and science and citizen action (bottom) timelines.

first session of the Citizen Science Lab show that the majority (56\%, $n=$ 14) of the participants already knew about CS, and that there was a strong consensus that library users could effectively participate in a CS project $(96 \%, n=24)$. There were, however, still some reservations about their degree of commitment: both at the beginning $(75 \%, n=18)$ and at the end $(79 \%, n=15)$ of the activity, the majority foresaw only a moderate level of user involvement. The main concerns raised by the librarians regarding user engagement had to do with user commitment $(n=5)$, unawareness or a lack of familiarity with CS $(n=4)$, and lack of time $(n=3)$.

Of the 26 projects that the librarians initially selected and tested themselves, or in some cases with library users, the majority $(n=19)$ were of the 'crowdsourcing' type; projects where participation is limited to the data collection process with minimal cognitive involvement. Many of the projects selected counted on the use of a mobile app ( $n=$ $11)$ or a web platform $(n=11)$ for data collection and were based on outdoor activities $(n=22)$. Some librarians pictured an informative talk with scientists to explain how the project and app worked, and to promote use of the app. Others planned to organize a one-day outdoor session in the surrounding of the library facilitated by scientists to collect data (Perelló et al., 2019).

Overall, the librarians expressed a high level of satisfaction. They declared that their initial expectations had been completely or mostly satisfied $(70 \%, n=17)$. The most significant fact is that, despite their low rate of prior participation in CS projects (only $8 \%$ reported previous participation) and their lack of a scientific background (only $4 \%$ reported one), at the end they expressed significantly higher confidence in their ability to contribute to or implement CS projects. Initially, at the beginning of the Citizen Science Lab, only $32 \%(n=8)$ of the librarians saw themselves as being capable of providing their users with content related to CS. However, by the end, everyone $(100 \%, \mathrm{n}=22)$ declared themselves able to recommend and explain some CS projects to library users, and they felt motivated to become more engaged in CS projects $(82 \%, n=18)$. Moreover, concerning the perceived capacity of the librarians to start a CS project on their own, almost twice as many declared themselves to be 'totally' or 'largely' confident at the end of the project $(44 \%, \mathrm{n}=8)$ as at the beginning $(21 \%, n=5)$. As shown in Fig. 3 (left), which represents the impact the librarians perceived CS to have, above all they saw in CS an opportunity to create new connections (mean $=1.68, \mathrm{SEM}=1.32$, where -2 corresponds to 'strongly disagree' and 2 corresponds to 'strongly agree'), to improve local knowledge (mean $=1.58, \mathrm{SEM}=1.22$ ), and to participate in a fun activity (mean = $1.47, \mathrm{SEM}=1.08$ ) that boosted social cohesion (mean $=1.47, \mathrm{SEM}=$ 1.20).

As for the co-creation framework of Science and Citizen Action, library users mainly cited personal motives, social networks, advocacy and socialization as the reasons underlying their participation, as opposed to being interested in CS (at the beginning, 94\% of users declared that they had never participated in CS projects before). Although from the very beginning of the activity the majority very much agreed that their library was close and attentive to the needs of the community $(57 \%, n=31)$ and they also agreed to a great extent that their library was able to face local challenges based on the active participation of its users $(89 \%, n=48)$, it was still the case that the majority agreed to a great extent that the public behavioral experiment had positively changed their perception of the library $(70 \%, n=16)$, and were very satisfied with the experiment $(70 \%, \mathrm{n}=16)$. Library users were further asked about their capacity to participate in CS. Table 1 shows some basic statistics that represent the confidence of the library user at performing scientific tasks, namely: research question formulation; data collection; data analysis; and transforming scientific evidence into specific proposals. At both the beginning and end of the activity, the 

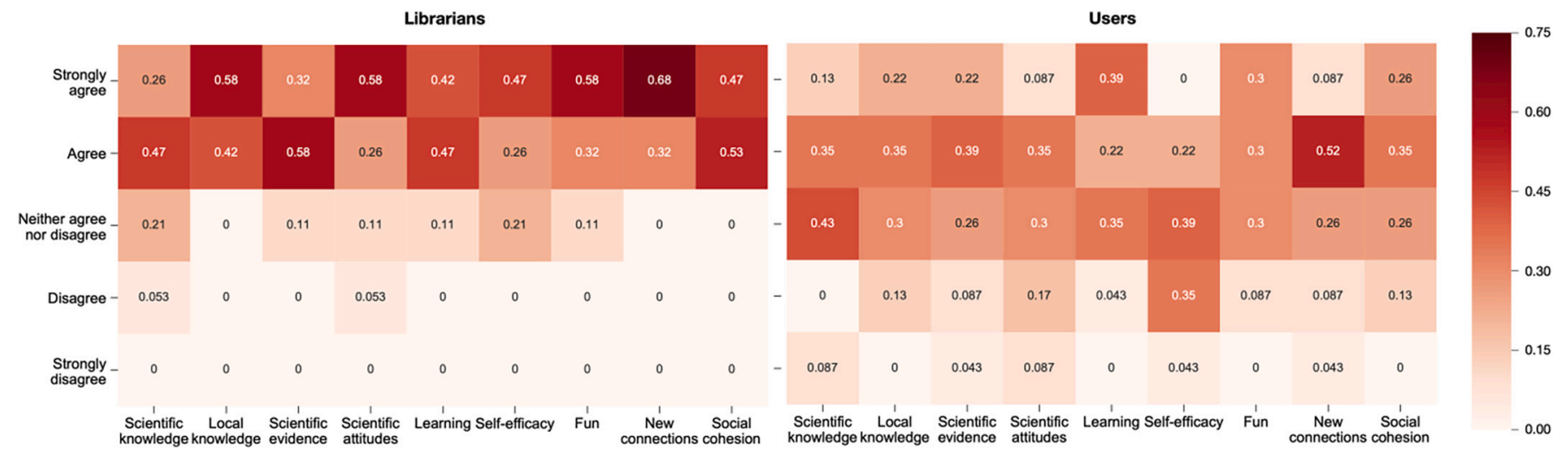

Fig. 3. The heat map shows the frequency of rankings of different dimensions of the impact of CS as perceived by librarians $(n=19)$ and library users $(n=23)$ at the end of the project. The dimensions are: increased knowledge of the scientific process (scientific knowledge); increased knowledge of the local community (local knowledge); scientific evidence regarding a common concern (scientific evidence); improved attitudes towards science (improved science attitudes); heightened willingness to learn (learning); improved self-efficacy when contributing to science (self-efficacy); fun (fun); new social connections between co-researchers (new connections); and social cohesion (social cohesion).

Table 1

Basic statistics reflecting users' confidence at performing scientific tasks. 1 missing value in the responses to the questionnaire at the beginning of Science and Citizen Action.

\begin{tabular}{|c|c|c|c|c|}
\hline & $\begin{array}{l}\text { Perceived } \\
\text { confidence at } \\
\text { formulating } \\
\text { the research } \\
\text { question }\end{array}$ & $\begin{array}{l}\text { Perceived } \\
\text { confidence } \\
\text { at collecting } \\
\text { the data }\end{array}$ & $\begin{array}{l}\text { Perceived } \\
\text { confidence } \\
\text { at analyzing } \\
\text { the data }\end{array}$ & $\begin{array}{l}\text { Perceived } \\
\text { confidence at } \\
\text { transforming } \\
\text { the scientific } \\
\text { evidence into } \\
\text { specific actions }\end{array}$ \\
\hline & Mean (SEM) & Mean (SEM) & Mean (SEM) & Mean (SEM) \\
\hline $\begin{array}{l}\text { Beginning } \\
\text { of science } \\
\text { and } \\
\text { citizen } \\
\text { action ( } n \\
=53 \text { ) }\end{array}$ & $0.66(0.03)$ & $0.62(0.03)$ & $0.59(0.03)$ & $0.63(0.03)$ \\
\hline $\begin{array}{l}\text { End of } \\
\text { science } \\
\text { and } \\
\text { citizen } \\
\text { action ( } n \\
=23 \text { ) }\end{array}$ & $0.58(0.05)$ & $0.55(0.05)$ & $0.53(0.06)$ & $0.64(0.05)$ \\
\hline
\end{tabular}

Mean and standard error of the mean (SEM) represent the normalized score of users' confidence at performing different scientific tasks (where 0 corresponds to 'not at all' and 1 corresponds to 'totally').

library users were slightly more likely to report feeling confident about transforming evidence into action $(0.63, \mathrm{SEM}=0.03$ and $0.64, \mathrm{SEM}=$ 0.05 , respectively) than about formulating the research question, or collecting and analyzing data (see Table 1). As shown in Fig. 3 (right), which represents the impact library users perceived CS to have, they indicated that participating in the project mainly increased their willingness to learn (mean $=0.96$, SEM $=0.84$ ); that it was a fun activity (mean $=0.83$, SEM $=0.70$ ); and that, in agreement with the views expressed by the librarians, it increased social cohesion among participants engaged in it (mean $=0.74$, SEM $=0.65$ ). See Fig. 3 .

\subsection{Focus group}

The most relevant challenges and further insights into the engagement of librarians in CS emerged from the focus group with the librarians at the end of the co-creation in the public behavioral experiments. Specifically, Table 2 represents a code map of the most commonly reported codes, and associated themes and subthemes, under each construct of the TPB model.
Table 2

Commonly reported theme and subtheme codes for each construct of the Theory of Planned Behavior model (Science and Citizen Action).

\begin{tabular}{lll}
\hline Construct & Theme & Code \\
\hline Attitudes & Learning and socialization & New resources \\
& & Social connections \\
& Complexity of & Emancipation \\
& collaboration & Openness \\
& & Retention \\
Subjective norms & Commitment & Diverging interests \\
& Inclusivity & Skepticism \\
& & Planning \\
& & Reading \\
Perceived behavioral & Workload & comprehension \\
control & Training & Material adaptation \\
& & Recruitment \\
& & Comfort zone \\
& & External support \\
& & Communication \\
& & Group management \\
& & Practical experience \\
\hline
\end{tabular}

Most commonly reported codes (and associated themes and subthemes) under each construct of the TPB model.

When asked about their views regarding co-created CS, the librarians referred to the opportunity that CS may provide to engage people with different perspectives in generating knowledge together, moving beyond traditional disciplinary fields. According to the librarians, the activity also attracted new library users and created new local connections. They agreed that the collaborative method helped to integrate the local concerns of the participants into the research. They further indicated the emancipatory potential of co-created CS and described a sense of awareness of the immediate surroundings that can be prompted by CS and which can, in turn, facilitate the building of relationships.

When asked about the returns for users after participating in the activity, concerns emerged regarding users' commitment and the inclusivity of the activity. According to the librarians, the open nature of the collaborative activity was viewed with certain skepticism by users. Continuous adaptive planning of the calendar was also highlighted as a potential barrier to user commitment. The librarians further indicated the difficulty involved in ensuring equity-driven recruitment of participants, with special reference to the reading comprehension of co-design material and data collection tools which participants sometimes found hard to understand. They commented on the high level of abstraction required which made the need to adapt the materials and mechanisms in order to guarantee inclusivity evident. The activity provided new 
resources for the library and promoted critical thinking among participants while enhancing social networks within the community.

When asked about their perceived ability to engage in co-created CS, the librarians underlined the opportunity that the activity offered them to learn new practices and the fact that interacting with professional scientists had changed their understanding of science. They did, however, express a certain unease regarding the complexity of collaboration. Their uncertainty associated with the co-creation dynamics was related to the difficulty in sustaining participation over time. The librarians also noted the different and even conflicting stakes that may be at odds in the research process. If, on the one hand, librarians aimed to attract new publics, on the other hand, professional scientists were concerned with scientific results. These two goals made them unclear as to the role of each participant. The librarians further highlighted the workload it implied, the need for training and the importance of practical experience. They found it difficult to implement and lead the activity, although they agreed that it was a dynamic process and the difficulties had reduced by the end. The workload was perceived as mainly related to participant recruitment and retention, and to moving out of one's comfort zone. They also stressed the fact that without the support of professional researchers, they would not have been able to manage the activity within their community. This led them to agree on the need for training to be able to lead and implement such activities, in terms of facilitation, communication, group management, and participation. The librarians emphasized the importance of practical experience in participatory and group dynamics which could then facilitate project implementation: administering the group, allowing for uncertainty, adaptability, and the possibility of transferring the methodology used to other library initiatives and processes.

Overall, when asked if they intended to remain engaged with CS and implement a project the following year, all the librarians answered positively. They also confirmed that their motivation was considerably higher than at the beginning.

\section{Discussion}

This study represents a novel empirical contribution to the evolving debate surrounding the role CS may play in reimagining public libraries as community hubs in order to adapt them to the changing societal landscape (Ignat et al., 2018; Ignat et al., 2019; OCLC and American Library Association, 2018; Ross \& Sennyey, 2008). After the training they received, results show that the library professionals felt confident in their ability to recommend CS projects to their users. The librarians envisaged both indoor and outdoor activities, mainly of a crowdsourcing type which do not require significant investment in technical expertise or infrastructure, but rather depend on online resources, low-cost tools or personal smartphones (Moorefield-Lang, 2015; Willett, 2018).

The study also explored whether co-created citizen social science projects can be successfully implemented in public libraries. Beyond a gain in STEM knowledge and skills (Bonney et al., 2016; Brossard et al., 2005; Perelló, Ferran-Ferrer, Ferré, Pou, \& Bonhoure, 2017), the potential of CS, especially in its co-created dimension (Senabre et al., 2018), may lie within a more social and playful dimension, which is in line with the mission of public libraries. According to the perceptions of the librarians and users participating in the activity, co-created citizen social science allows social bonds among the participants to be strengthened, knowledge of the environment to be increased and perceptions of the social value of the library and its surroundings to be improved. Doing science with and for the participants pushes CS beyond the scope of knowledge and skill development, enhancing individual sense and critical connection to place (Calabrese Barton, 2012; Haywood et al., 2016; Newman et al., 2017). Co-created projects invite genuine participation through trust, creativity and transparency (Senabre et al., 2018), as well as critical engagement. This encourages library users to take an active role in addressing common concerns, alongside scientists, that revolve around science-based community issues
(Sauermann et al., 2020). Co-created citizen social science may further constitute an opportunity for public libraries to reinforce their role as powerful community networks that promote civic engagement and cultural opportunities (Aabø et al., 2010), acting as what Kranich (2010) called "civic learning agents".

Nevertheless, the librarians expressed a certain unease with the complexity of the collaboration, which should be taken into account during the planning of the participatory dynamics. Some of the main challenges identified were uncertainty regarding the open nature of a cocreated inquiry (Senabre et al., 2018), the conflicting stakes and interests of citizens, librarians and scientists which could be at odds with each other in the research process (Eleta, Clavell, Righi, \& Balestrini, 2019), and the difficulty involved in ensuring equity-driven recruitment and retention of participants during the whole process (Shirk et al., 2012). Co-created practices certainly modify the relationship between librarians and users, shifting them towards a more participatory and horizontal interaction. As the librarians pointed out, the possession of 'soft skills' (e.g. facilitation, management, communication and participation) is crucial for libraries to engage with CS more fully (Ignat et al., 2018). Soft skills are needed for the transformative use of means and resources, to strengthen social cooperation, and for the resolution of cognitive and social challenges (Greenhalgh \& Worpole, 2013; Leckie \& Hopkins, 2002; Ross \& Sennyey, 2008).

\subsection{Limitations}

The exploratory nature of the analysis, the small sample size, and the self-selected sample of library users reduce the extent to which the findings can be generalized and limit their representativeness on the grounds of age, gender or sociocultural background.

\section{Conclusions}

Public libraries face a paradigm shift in their community role sparked by societal changes and the impact of more open, transparent and democratic ways of understanding knowledge production and access fostered by the digital revolution. Public libraries have thus modified the services they provide, from delivering public Internet access, to offering digital media content, and developing and supporting activities aimed at promoting access to knowledge through experimentation and innovative and creative methodologies, as in the case of Bibliolab (Barcelona, Spain). A recent survey reports that in 2018, 39.9\% of the population in the Spanish region of Catalonia had visited a public library in the previous year, and that figure has increased compared to 2013 when $33.9 \%$ declared visiting a public library prior to the survey (Diputació Barcelona, 2020). However, the proportion of individuals aged between 14 and 24 who reported visiting a public library in Catalonia decreased overall, with only a minimal number of users of all ages attending some sort of educational activity beyond borrowing books or reading (Diputació Barcelona, 2020). Libraries may thus find a welcome opportunity in CS and within the broader open science movement, but this might require the development of novel infrastructure, materials and guidelines, as well as the building of skills and partnerships in order to successfully advocate for CS (Ayris \& Ignat, 2018; Ignat et al., 2018; Ignat \& Ayris, 2020).

Overall, this study suggests that public libraries can embrace CS practices and indeed may offer leadership in the promotion and implementation of CS initiatives (Ayris \& Ignat, 2018; Ignat et al., 2018; Ignat et al., 2019; Wiederkehr, 2019). According to the perceptions of librarians, involving public libraries in CS may enable alternative learning experiences which, coupled with increased social cohesion, could generate new perspectives on public libraries where knowledge is not only shared but also constructed in a horizontal and collective way (Senabre et al., 2018). Libraries are thus seen as transcultural and transgenerational meeting spaces where knowledge is shared and communicated beyond disciplinary boundaries, and which may 
facilitate social changes through fostering curiosity, knowledge, culture and science (Wojciechowska, 2020). They could thus be conceived of as spaces where people, groups and communities practice CS to build community and citizenship, which may be considered the main strength behind further embracing CS practices in public libraries.

\section{Funding}

This work was partially supported by Xarxa de Biblioteques Municipals de Barcelona (Diputació de Barcelona); by MINEICO (Spain), Agencia Estatal de Investigación (AEI) and Fondo Europeo de Desarrollo Regional (FEDER) through grants FIS2016-78904-C3-2-P and PID2019106811 GB-C33 (AC, IB, and JP); by Generalitat de Catalunya (Spain) through Complexity Lab Barcelona (contract no. 2017 SGR 608); by the European Union's Horizon 2020 research and innovation programme (CoAct, under grant agreement no. 873048; AC, IB, and JP).

\section{Acknowledgments}

The authors would like to thank librarians from the 24 public libraries participating in the Citizen Science Lab: Biblioteca Mercè Rodoreda (Sant Joan Despí), Biblioteca Ramon Fernàndez Jurado (Castelldefels), Biblioteca Antonio Martin (El Prat de Llobregat), Biblioteca Joan Coromines (Masnou), Biblioteca bd5 (Terrassa), Biblioteca Can Casacuberta (Badalona), Biblioteca de Viladecans (Viladecans), Biblioteca Santa Oliva (Olesa de Montserrat), Biblioteca L'Ateneu (Esparreguera), Biblioteca Sagrada Família - Josep M. Ainaud de Lasarte (Barcelona), Biblioteca Fort Pienc (Barcelona), Biblioteca de Bigues i Riells (Bigues i Riells), Biblioteca Can Pedrals (Granollers), Biblioteca Roca Umbert (Granollers), Biblioteca Ernest Lluch i Martin (Vilassar de Mar), Biblioteca Municipal (Cervelló), Biblioteca La Grua (Montmeló), Biblioteca Central (Cerdanyola del Vallès), Biblioteca Volpelleres - Sant Miquel Batllori (Sant Cugat), Biblioteca Josep Janés (L'Hospitalet de Llobregat), Biblioteca El Molí (Molins de Rei), Biblioteca Montserrat Roig (Sant Feliu de Llobregat), Biblioteca de Sant Antoni de Vilamajor (Sant Antoni de Vilamajor), Biblioteca Joan Oliva i Milà (Vilanova i la Geltrú). The authors would particularly like to thank the librarians and users of: Biblioteca Santa Oliva (Olesa de Montserrat), Biblioteca Fort Pienc (Barcelona), Biblioteca Can Pedrals (Granollers) and Biblioteca Roca Umbert (Granollers). The authors would also like to thank Montserrat Álvarez, Marta Cano and the Gerència de Serveis de Biblioteques of the Barcelona Provincial Council who all made possible, together with their communities and local administrations, the activity.

\section{References}

Aabø, S., Audunson, R., \& Vårheim, A. (2010). How do public libraries function as meeting places? Library \& Information Science Research, 32, 16-26. https://doi.org/ 10.1016/j.lisr.2009.07.008.

Ajzen, I. (1991). The theory of planned behavior. Organizational Behavior and Human Decision Processes, 50, 179-211.

Ayris, P., \& Ignat, T. (2018). Defining the role of libraries in the Open Science landscape: a reflection on current European practice. Open Information Science, 2(1), 1-22. https://doi.org/10.1515/opis-2018-0001.

Bela, G., Peltola, T., Young, J. C., Balázs, B., Arpin, I., Pataki, G., ... Bonn, A. (2016). Learning and the transformative potential of citizen science. Conservation Biology, 30 990-999. https://doi.org/10.1111/cobi.12762.

Bonhoure, I., Cigarini, A., Vicens, J., \& Perelló, J. (2019). Citizen social science in practice: A critical analysis of a mental health community-based project. SocArXiv. doi:10.31235/osf.io/63aj7.

Bonney, R., Phillips, T. B., Ballard, H. L., \& Enck, J. W. (2016). Can citizen science enhance public understanding of science? Public Understanding of Science, 25(1), 2-16. https://doi.org/10.1177/0963662515607406.

Braun, V., \& Clarke, V. (2006). Using thematic analysis in psychology. Qualitative Research in Psychology, 3, 77-101. https://doi.org/10.1191/1478088706qp063oa.

Brossard, D., Lewenstein, B., \& Bonney, R. (2005). Scientific knowledge and attitude change: The impact of a citizen science project. International Journal of Science Education, 27, 1099-1121. https://doi.org/10.1080/09500690500069483.

Calabrese Barton, A. M. (2012). Citizen(s') science. A response to "The future of citizen science". Democracy and Education, 20(2), 12. https://bit.ly/30W0AV2.

Dickinson, J. L., Shirk, J., Bonter, D., Bonney, R., Crain, R., Martin, J., et al. (2012). The current state of citizen science as a tool for ecological research and public engagement. Frontiers in Ecology and the Environment, 10, 291-297. https://doi.org/ $10.1890 / 110236$.

Diputació Barcelona. (2020). Estudi dels resultats de l'Enquesta de satisfacció dels usuaris de la Xarxa de Biblioteques Municipals (XBM) de la demarcació de Barcelona. Retrieved from https://www.diba.cat/documents/16060163/3430717 54/200127+Informe+Satisfacci\%C3\%B3+Usuaris+XBM+Barcelona.pdf/b1db3e 36-a017-e6c7-16b1-dc65b4b5d35c?t=1602585855896.

Eleta, I., Clavell, G. G., Righi, V., \& Balestrini, M. (2019). The promise of participation and decision-making power in citizen science. Citizen Science: Theory and Practice, 4 (1). https://doi.org/10.5334/cstp.171.

Fraisl, D., Campbell, J., See, L., Wehn, U., Wardlaw, J., Gold, M., ... Masó, J. (2020). Mapping citizen science contributions to the UN sustainable development goals. Sustainability Science, 15, 1735-1751. https://doi.org/10.1007/s11625-020-008337.

Greenhalgh, L., \& Worpole, K. (2013). Libraries in a world of cultural change. London, England: Routledge.

Haywood, B. K., Parrish, J. K., \& Dolliver, J. (2016). Place-based and data-rich citizen science as a precursor for conservation action. Conservation Biology, 30, 476-486. https://doi.org/10.1111/cobi.12702.

Ignat, T., \& Ayris, P. (2020). Built to last! Embedding open science principles and practice into European universities. Insights, 33, 9. https://doi.org/10.1629/ uksg.501.

Ignat, T., Ayris, P., Labastida, I., Juan, I., Reilly, S., Dorch, B., ... Overgaard, A. K. (2018). Merry work: Libraries and citizen science. Insights, 31, 35. https://doi.org/10.1629/ uksg. 431.

Ignat, T., Cavalier, D., \& Nickerson, C. (2019). Citizen science and libraries: Waltzing towards a collaboration. Mitteilungen der Vereinigung Österreichischer Bibliothekarinnen und Bibliothekare, 72, 328-336. https://doi.org/10.31263/voebm.v72i2.3047.

Ingraham, C. (2015). Libraries and their publics: Rhetorics of the public library. Rhetoric Review, 34, 147-163. https://doi.org/10.1080/07350198.2015.1008915.

Irwin, A. (1995). Citizen science. London, England: Routledge.

Johnson, M. F., Hannah, C., Acton, L., Popovici, R., Karanth, K. K., \& Weinthal, E. (2014). Network environmentalism: Citizen scientists as agents for environmental advocacy. Global Environmental Change, 29, 235-245. https://doi.org/10.1016/j. gloenvcha.2014.10.006.

Kranich, N. (2010). Promoting adult learning through civil discourse in the public library. New Directions for Adult and Continuing Education, 2010(127), 15-24. https:// doi.org/10.1002/ace.377.

League of European Research Universities. (2016). Citizen science at universities: Trends, guidelines, and recommendations. Advice Paper, 20. Retrieved from https://www.le ru.org/publications/citizen-science-at-universities-trends-guidelines-and-recomme ndations.

League of European Research Universities. (2018). Open science and its role in universities: A roadmap for cultural change. Leuven: LERU. Advice Paper, 24. retrieved from https ://www.leru.org/files/LERU-AP24-Open-Science-full-paper.pdf.

Leckie, G. J., \& Hopkins, J. (2002). The public place of central libraries: Findings from Toronto and Vancouver. The Library Quarterly, 72, 326-372. https://doi.org/ 10.1086/lq.72.3.40039762.

McKinley, D. C., Miller-Rushing, A. J., Ballard, H. L., Bonney, R., Brown, H., \& Evans, D. M. (2017). Citizen science can improve conservation science, natural resource management, and environmental protection. Biological Conservation, 208, 15-28. https://doi.org/10.1016/j.biocon.2016.05.015.

Moorefield-Lang, H. M. (2015). When makerspaces go mobile: Case studies of transportable maker locations. Library Hi Tech, 33, 462-471. https://doi.org/ 10.1108/lht-06-2015-0061.

Newman, G., Chandler, M., Clyde, M., McGreavy, B., Haklay, M., Ballard, H., ... Gallo, J. (2017). Leveraging the power of place in citizen science for effective conservation decision making. Biological Conservation, 208, 55-64. https://doi.org/10.1016/j. biocon.2016.07.019.

Nov, O., Arazy, O., \& Anderson, D. (2014). Scientists@ home: What drives the quantity and quality of online citizen science participation? PLoS One, 9(4), Article e90375. https://doi.org/10.1371/journal.pone.0090375.

OCLC and American Library Association. (2018). From awareness to funding: Voter perceptions and support of public libraries in 2018. Dublin, OH: OCLC. https://doi.org/ 10.25333/C3M92X.

Perelló, J., Bonhoure, I., Cigarini, A., \& Vicens, J. (2019). Ciència ciutadana a les biblioteques: Observa, analitza, crea i participa. Zenodo. https://doi.org/10.5281/ zenodo.3490610.

Perelló, J., Ferran-Ferrer, N., Ferré, S., Pou, T., \& Bonhoure, I. (2017). High motivation and relevant scientific competencies through the introduction of citizen science at secondary schools. In Citizen inquiry (pp. 150-175). London, England: Routledge. https://doi.org/10.4324/9781315458618-9.

Phillips, T. B., Ballard, H. L., Lewenstein, B. V., \& Bonney, R. (2019). Engagement in science through citizen science: Moving beyond data collection. Science Education, 103, 665-690. https://doi.org/10.1002/sce.21501.

Ross, L., \& Sennyey, P. (2008). The library is dead, long live the library! The practice of academic librarianship and the digital revolution. The Journal of Academic Librarianship, 34, 145-152. https://doi.org/10.1016/j.acalib.2007.12.006.

Sanders, E. B. N., \& Stappers, P. J. (2008). Co-creation and the new landscapes of design. Co-design, 4(1), 5-18. https://doi.org/10.5040/9781474282932.0011.

Sauermann, H., Vohland, K., Antoniou, V., Balázs, B., Göbel, C., Karatzas, K., Winter, S. (2020). Citizen science and sustainability transitions. Research Policy, 49 (5), 103978. https://doi.org/10.1016/j.respol.2020.103978.

SciStarter. (2019). The librarian's guide to citizen science. Retrieved from https://s3-us -west-2.amazonaws.com/orrery-media/misc/CitSci Librarians_Guide_02 22 r1.pdf. 
Senabre, E., Ferran-Ferrer, N., \& Perelló, J. (2018). Participatory design of citizen science experiments [Diseño participativo de experimentos de ciencia ciudadana]. Comunicar. Media Education Research Journal, 26(1), 29-38. https://doi.org/ 10.3916/c54-2018-03.

Shirk, J. L., Ballard, H. L., Wilderman, C. C., Phillips, T., Wiggins, A., Jordan, R., ... Bonney, R. (2012). Public participation in scientific research: A framework for deliberate design. Ecology and Society, 17(2), 29. https://doi.org/10.5751/ES-04705 $-170229$.

Vicens, J., Perelló, J., \& Duch, J. (2018). Citizen social lab: A digital platform for human behavior experimentation within a citizen science framework. PLoS One, 13(12), Article e0207219. https://doi.org/10.1371/journal.pone.0207219.

Wehn, U., Gobel, C., Bowser, A., Hepburn, L., \& Haklay, M. (2020). Global citizen science perspectives on Open Science. CSGP Citizen Science \& Open Science Community of Practice to the UNESCO Recommendation on Open Science. https://osf.io/6qjyg/.

Wiederkehr, S. (2019). Open data for the crowd: An account of citizen science at ETH library. LIBER Quarterly, 29, 1-10. https://doi.org/10.18352/lq.10294.

Willett, R. (2018). Learning through making in public libraries: Theories, practices, and tensions. Learning, Media and Technology, 43, 250-262. https://doi.org/10.1080/ 17439884.2017.1369107.

Wojciechowska, M. (2020). Social capital, trust and social activity among librarians: Results of research conducted in 20 countries across the world. Library \& Information Science Research, 42, 101049. https://doi.org/10.1016/j.lisr.2020.101049.

Anna Cigarini is a $\mathrm{PhD}$ candidate in information and knowledge society at the Internet Interdisciplinary Institute (Universitat Oberta de Catalunya). Since 2016 she is a member of OpenSystems at Universitat de Barcelona, and member of the Universitat de Barcelona Institute of Complex Systems. Her research interests cover individual and collective decision-making, citizen science, participatory research approaches, and the conditions that favor value creation and governance in collaborative knowledge production processes. She has published her research in journals such as Scientific Reports.
Isabelle Bonhoure has a $\mathrm{PhD}$ in materials science (Université Paris $\mathrm{XI}$ ) and a Masters in science communication (Universitat Pompeu Fabra). In 2013, she joined OpenSystems at Universitat de Barcelona, and she is a member of the Universitat de Barcelona Institute of Complex Systems. As a researcher, she is particularly interested in citizen social science and its implications in terms of bottom-up co-creation processes, involvement of citizens in a vulnerable situation and practical implementation of responsible research. She has published her research in journals such as Frontiers in Physics, BMC Public Health and Environmental Science and Technology.

Julián Vicens is a research scientist within the Data Science and Big Data unit at Fundació Eurecat. His research interests span transdisciplinary fields such as complex systems, computational social science, and citizen science. He studies topics such as individual and collective behavior, machine learning, algorithmic fairness and participatory platforms, publishing the results of his research in top-tier journals such as Science Advances and Scientific Reports. Julián also works in national and international projects which focus on studying and unveiling inequalities within social systems.

Josep Perelló is a full professor at the Universitat de Barcelona, and research member of Universitat de Barcelona Institute of Complex Systems. He holds a $\mathrm{PhD}$ in physics (Universitat de Barcelona). In 2013, he founded OpenSystems to run transdisciplinary scientific research with the crucial contributions through citizens' participation and with artistic practices. His research interests span transdisciplinary fields such as complex systems, collective human behavior, computational social science, and citizen science. He has published his research in international journals such as Nature Communications, Science Advances, Scientific Reports, EPJ Data Science and Plos ONE covering the following fields: multidisciplinary science, mathematical physics, condensed matter physics, economics, financial mathematics, finance, environmental economics, behavioral sciences, mobility and citizen science. 